\title{
KORELASI KECANDUAN MOBILE LEGENDS TERHADAP PRESTASI BELAJAR MAHASISWA
}

\author{
Diki Irwandi ${ }^{1}$, Ruhban Masykur ${ }^{2}$, Suherman ${ }^{3}$ \\ ${ }^{1,2,3}$ Universitas Islam Negeri Raden Intan Lampung \\ dikiirwandi3@gmail.com¹, Ruhbanmaskur@ radenintan.ac.id ${ }^{2}$, \\ suherman@ radenintan.ac.id ${ }^{3}$
}

\begin{abstract}
The purpose of the study was to determine the correlation between the level of online game addiction and student achievement in the Mathematics Education Study Program, UIN Raden Intan Lampung. The method in this research was quantitative with the type of correlation research. The data collection technique used a questionnaire and tested it to see the validity and reliability. The data analysis technique in this study used the normality test using the Kolmogorov Smirnov method and the linearity test using SPSS software version 24.0, and hypothesis testing using a correlation test with a significant level of 0.05 or $5 \%$. The study results were that of the 30 questionnaires tested, 25 questions were feasible to use. The reliability test has a value of $r_{\text {count }}>r_{\text {table. }}$. The normality test got a significant value of 0.065 and 0.066 on online game addiction and learning achievement. So it can be said that there is a significant correlation between student achievement and online game addiction, and the value is 0.307 , which means correlation.
\end{abstract}

Keywords: Learning Achievement, Game Online Mobile Legends, Addiction Level

\begin{abstract}
Abstrak
Tujuan dari penelitian yaitu untuk mengetahui korelasi tingkat kecanduan Game Online dengan prestasi belajar mahasiswa prodi Pendidikan Matematika Universitas Islam Negeri Raden Intan Lampung. Metode pada penelitian ini yaitu kuantitatif dengan jenis penelitian korelasi. Teknik pengumpulan data menggunakan dengan angket kemudian dilakukan uji validitas dan reabilitas. Teknik analisis data pada penelitian ini menggunakan Uji normalitas menggunakan metode Kolmogrov Smirnov dan Uji linearitas menggunakan bantuan program SPSS 24.0 serta Uji hipotesis menggunakann uji korelasi dengan taraf signifikan 0,05 atau 5\%. Hasil pada penelitian ialah dari 30 angket yang diuji terdapat 25 pertanyaan yang layak untuk digunakan. Pada uji reabilitas memiliki nilai $r_{\text {hitung }}>r_{\text {tabel. }}$ Pada uji normalitas mendapatkan nilai signifikan 0,065 dan 0,066 pada kecanduan game online dan prestasi belajar. Sehingga dapat disimpulkan bahwa terdapat korelasi yang signifikan antara prestasi belajar mahasiswa dengan tingkat kecanduan Game Online, serta nilai $r$ yaitu 0,307 yang berarti korelasi rendah.
\end{abstract}

Kata kunci: Prestasi Belajar, Game Online Mobile Legends, Tingkat Kecanduan 
Jurnal Lebesgue : Jurnal Ilmiah Pendidikan Matematika, Matematika dan Statistika

Diki Irwandi, Ruhban Masykur, Suherman

Volume 2, No. 3, Desember 2021 hal.292-299

DOI Artikel : 10.46306/lb.v2i3.87

\section{PENDAHULUAN}

Seiring berkembangnya teknologi yang semakin canggih senantiasa mempengaruhi aspek kehidupan manusia. Salah satu perkembangan di bidang teknologi yaitu dengan internet yang semakin pesat, hal ini ditandai dengan munculnya salah satu jenis permainan audio visual dan komputer yaitu game elektronik, salah satu contohnya yaitu Game Onlin (N. K. W. Putra, 2017). Game Online adalah salah satu perkembangan internet yang cepat berkembang dan sangat digemari banyak orang karena permainan ini dapat dimainkan secara tim atau pun invidu selain itu permanian ini juga cukup menghubungkan ke suatu jaringan (Putra P, 2017). Banyaknya peminat Game Online dapat disebabkan oleh semakin baiknya mutu dan kualitas Game Online yang ada pada sekarang ini. Bermain Game Online akan berdampak negatif apabila dimainkan secara berlebihan dan hal ini dapat menyebabkan kecanduan. Kecanduan merupakan suatu perilaku yang tidak sehat dan berlangsung secara terus enerus yang sulit diakhiri oleh individu yang bersangkutan (Ramadhan et al., 2020). Game Online memiliki dampak positif dan negatif, dampak negatif untuk pendidikan yaitu menurunnya hasil belajar yang mengakibatkan prestasi seseorang dapat turun derastis akibat seseorang tersebut terlalu senang bermain Game Online yang menyebabkan lupa untuk belajar. Winkel mengatakan bahwa prestasi belajar merupakan suatu bukti keberhasilan belajar atau kemampuan seorang siswa dalam melakukan kegiatan belajar sesuai dengan bobot yang dicapainya (Ghullam Hamdu. Lisa Agustina, 2011). Sehingga perlunya perhatian pada proses pembelajaran agar memiliki hasil prestasi belajar (Suherman et al., 2021).

Pentingnya Game Online dalam kehidupan sehari-hari yakni, 1) Meningkatkan kemampuan berkonsentrasi. Permainan Game Online akan melatih pemainnya untuk dapat memenangkan permainan secara cepat dan dapat menghasilkan poin yang banyak, 2) Meningkatkan motoric, koordinasi mata dengan tangan, 3) Meningkatkan kemampuan berbahasa inggris, kebanyakan permainan Game Online menggunakan Bahasa inggris dalam pengoperasiannya dan hal tersebut yang menyebabkan pemainnya harus mampu menguasai kosa kata dalam Bahasa inggris, 4) Meningkatkan kemampuan membaca (F. F. Putra et al., 2019). Dilain pihak, diperlukan upaya dalam menyelaskan antara kemampuan non-kognitif dengan kognitif. Dalam hal ini yaitu prestasi belajar. Mengingat bahwa prestasi belajar memiliki peranan penting yaitu perubahan tingkah laku, keterampilan dan pengetahuan pada siswa setelah mengikuti proses belajar mengajar (Astuti, 2015).

Salah satu Game Online yang sering dimainkan yaitu Mobile Legends. Mobile Legends bangbang merupakan sebuah game developer dari Moonton. Mobile Legends bang-bang dirilis pada 
Jurnal Lebesgue : Jurnal Ilmiah Pendidikan Matematika, Matematika dan Statistika

Diki Irwandi, Ruhban Masykur, Suherman

Volume 2, No. 3, Desember 2021 hal.292-299

DOI Artikel : 10.46306/lb.v2i3.87

Android di China, Indonesia, Malaysia pada tanggal 11 Juli 2016 dan IOS di rilis pada tanggal 9 November 2016. Genre game ini adalah MOBA yang di desain untuk pengguna smartphone dengan tambahan virtual pad Game Online Mobile Legends merupakan jenis game yang saat ini sedang banyak diminati, game ini berbasis MOBA (Massive Online Battle Arena). Yaitu genre Game Online yang memadukan antara jenis genre game Real Time Strategi (RTS) dan Role Playing Game (RPG) dimana pemain menjalankan satu karakter dari dua tim yang berlawanan dengan tujuan untuk menghancurkan markas lawan. Setiap karakter hero yang dimainkan memiliki skill dengan kelebihan dan kekurangan masing-masing sehingga dituntut untuk bekerja sama dengan anggota tim untuk memenangkan pertandingan seperti Dota, League Of Legends (Ramadani Febri Iqbal Muhammad, 2018).

Hasil dari penelitian terdahulu yang dilakukan oleh (Maulidar et al., 2019) menyatakan bahwa adanya hubungan intensitas bermain Game Online dengan prestasi belajar siswa. Penelitian ini memiliki kekurangan bahwa sampel yang digunakan sedikit. Sedangkan penelitian lain menemukan bahwa game digital mendapatkan respon positif dari peserta didik tanpa memandang jenis kelamin serta konten game dalam genre moderat mengurangi pengaruh gender terhadap prestasi belajar dan motivasi (Chung \& Chang, 2017). Kekurangan penelitian ini tidak dijelaskan jenis game yang digunakan. Hasil penelitian lainnya yaitu penelitian yang dilakukan oleh (Wibisono \& Naryoso, 2019) menyatakan bahwa adanya hubungan intensitas bermain Game Online Mobile Legends dan pengawasan orang tua dengan perilaku verbal pada anak remaja. Penelitian lainnya yang dilakukan oleh (Jannah \& Nirwana, 2015) hasil dari penelitian tersebut menyatakan terdapat hubungan kecanduan game dengan motivasi belajar siswa dan implikasinya terhadap bimbingan dan konseling. Namun memiliki kekurangan bahwa game yang diberikan bersifat apasaja dan tidak ditentukan.

Berdasarkan beberapa penelitian terdahulu, penelitian ini memiliki kebaruan yaitu memfokuskan pada jenis game moblie legends yag sering digunakan. Kemudian penulis akan memfokuskan penelitian ini pada korelasi tingkat kecanduan Game Online Mobile Legends dengan prestasi belajar prodi mahasiswa pendidikan matematika dan inilah yang membedakan penelitian ini dengan penelitian terdahulu. Sehingga tujuan dari penelitian ini yaitu untuk mengetahui adanya korelasi antara tingkat kecanduan Game Online Mobile Legends dengan prestasi belajar mahasiswa prodi pendidikan matematika. 
Jurnal Lebesgue : Jurnal Ilmiah Pendidikan Matematika, Matematika dan Statistika

Diki Irwandi, Ruhban Masykur, Suherman

Volume 2, No. 3, Desember 2021 hal.292-299

DOI Artikel : 10.46306/lb.v2i3.87

\section{METODE PENELITIAN}

Dalam penelitian ini, penulis menggunakan metode penelitian kuantitatif dengan jenis penelitian korelasi. Instrument yang digunakan berupa angket. Teknik pengambilan sampel dengan teknik purposive sampling (Sugiyono, 2015) dengan jumlah sampel sebanyak 55 mahasiswa prodi pendidikan matematika. Teknik pengumpulan data yang digunakan pada penelitian ini yaitu kuesioner (angket) (Alqusyairi et al., 2021) tentang kecanduan Game Online untuk untuk mengetahui tingkat kecanduan mahasiswa terhadap Game Online, wawancara dan dokumentasi. Untuk mengukur kelayakan instrument digunakan uji validitas dan uji reliabilitas (Chusni \& Suherman, 2021). Selanjutnya untuk analisis data yang telah diperoleh, penulis melakukan uji prasyarat yaitu uji normalitas dan uji linearitas dengan bantuan program SPSS 24.0 dan uji hipotesis menggunakan uji Korelasi Product Moment (Hanief \& Himawanto, 2018).

\section{HASIL DAN PEMBAHASAN}

Instrument yang digunakan dalam penelitian ini ialah kuesioner (angket). Sebelum angket dibagikan kepada mahasiswa pendidikan matematika angkatan 2017, penulis melakukan uji coba angket terlebih dahulu kepada mahasiswa pendidikan matematika angkatan 2018. Dari 30 butir angket yang dibagikan, terdapat 25 butir angket yang layak digunakan dalam penelitian sedangkan 5 butir angket tidak layak digunakan. Kemudian penulis melakukan analisis data meliputi uji normalitas, uji linearitas dan uji korelasi product moment.

Uji normalitas digunakan untuk mengetahui apakah sampel berasal dari populasi yang berdistribusi normal atau tidak. Uji normalitas dilakukan dengan menggunakan bantuan program SPSS 24.0 dengan metode Kolmogorov Smirnov. Hasil uji normalitas dapat dilihat pada table berikut ini:

Tabel 1. Hasil Uji Normalitas

\begin{tabular}{llll}
\hline & \multicolumn{3}{l}{ Kolmogorov-Smirnov } \\
\cline { 2 - 4 } & Statistic & Df & Sig. \\
\hline KGO & .116 & 55 & .065 \\
\hline PRESTASI & .115 & 55 & .066 \\
\hline
\end{tabular}

Berdasarkan table di atas dapat dilihat bahwa nilai sig pada variable KGO dan PRESTASI lebih dari 0,05 sehingga $\boldsymbol{H}_{\mathbf{0}}$ diterima yang berarti sampel berasal dari populasi yang berdistribusi 
Jurnal Lebesgue : Jurnal Ilmiah Pendidikan Matematika, Matematika dan Statistika

Diki Irwandi, Ruhban Masykur, Suherman

Volume 2, No. 3, Desember 2021 hal.292-299

DOI Artikel : 10.46306/lb.v2i3.87

normal. Setelah dilakukan uji normalitas, langkah selanjutnya yaitu uji linearitas. Uji linearitas pada penelitian ini dilakukan dengan bantuan program SPSS 24.0, uji linearitas digunakan untuk mengetahui apakah variable $\mathrm{X}$ dan variable $\mathrm{Y}$ memiliki hubungan yang linier. Berikut adalah hasil uji linearitas:

Table 2. Hasil Uji Linearitas

\begin{tabular}{|c|c|c|c|c|c|c|c|}
\hline & & & $\begin{array}{l}\text { Sum of } \\
\text { Squares }\end{array}$ & Df & $\begin{array}{c}\text { Mean } \\
\text { Square }\end{array}$ & $\mathbf{F}$ & Sig. \\
\hline \multirow{6}{*}{ PRESTASI*KGO } & Between & (Combined) & .577 & 19 & .030 & 1.520 & .139 \\
\hline & Groups & Linearity & .121 & 1 & .121 & 6.030 & .019 \\
\hline & & Deviation from & .457 & 18 & .025 & 1.269 & .265 \\
\hline & & Linearity & & & & & \\
\hline & \multicolumn{2}{|c|}{ Within Groups } & .509 & .700 & 35 & .020 & \\
\hline & \multicolumn{2}{|l|}{ Total } & .768 & 1.277 & 54 & & \\
\hline
\end{tabular}

Berdasarkan hasil uji linearitas di atas, dapat dilihat bahwa nilai sig lebih dari 0,05 yang berarti variable X dan Y mempunyai hubungan yang linier. Setelah syarat uji normalitas dan linearitas terpenuhi, selanjutnya dilakukan uji hipotesis korelasi product moment untuk mengetahui apakah terdapat hubungan antara tingkat kecanduan Game Online dengan prestasi belajar mahasiswa pendidikan matematika angkatan 2017. Hasil uji hipotesis korelasi dapat dilihat dalam table berikut ini:

Tabel 3. Uji Hipotesis Korelasi

\begin{tabular}{llcc}
\hline & & KGO & PRESTASI \\
\hline \multirow{2}{*}{ KGO } & Pearson Correlation & 1 & $.307^{*}$ \\
\cline { 2 - 4 } & Sig. (2-tailed) & & .023 \\
\cline { 2 - 4 } $\mathrm{N}$ & 55 & 55 \\
\hline \multirow{2}{*}{ PRESTASI } & Pearson Correlation & $.307^{*}$ & 1 \\
\cline { 2 - 4 } & Sig. (2-tailed) & .023 & \\
\cline { 2 - 4 } & $\mathrm{N}$ & 55 & 55 \\
\hline
\end{tabular}

Dari hasil uji korelasi di atas dapat dilihat bahwa nilai sig lebih kecil dari 0,05 yang berarti terdapat hubungan yang signifikan antara tingkat kecanduan Game Online Mobile Legends dengan 
Jurnal Lebesgue : Jurnal Ilmiah Pendidikan Matematika, Matematika dan Statistika

Diki Irwandi, Ruhban Masykur, Suherman

Volume 2, No. 3, Desember 2021 hal.292-299

DOI Artikel : 10.46306/lb.v2i3.87

prestasi belajar mahasiswa pendidikan matematika angkatan 2017 dengan nilai koefisien korelasi sebesar 0,307 yang masuk dalam kategori sedang. Sehingga $\boldsymbol{H}_{\mathbf{0}}$ diterima yang berarti terdapat korelasi antara tingkat kecanduan Game Online Mobile Legends dengan prestasi belajar mahasiswa prodi pendidikan matematika. Mengingat bahwa prestasi belajar sangat diperlukan, sehingga adanya korelasi ini akan menjadi dampak yang baik terhadap bagaimana seseorang dapat menggunakan waktu untuk belajar serta pengarunhya terhadap pembentukan karakter belajar (Huda et al., 2019; Yunianto et al., 2020).

Hal ini juga senada dengan penelitian yang dilakukan oleh (Julia, 2018), hasil dari penelitian tersebut menunjukkan bahwa terdapat hubungan yang signifikan antara kecanduan internet Game Online terhadap prestasi belajar siswa di SD N 53 Banda Aceh dengan nilai korelasi sangat tinggi. Penelitian yang senada juga dilakukan (Ehwanudin, 2020), hasil dari penelitian tersebut menyatakan bahwa adanya hubungan intensitas bermain Game Online dengan perilaku keberagaman siswa SMP Muhammadiyah Plus Salatiga tahun ajaran 2019/2020 dengan nilai koefisien $\mathrm{r}$ sebesar 0,444 yang berarti memiliki korelasi sedang. Penelitian lain yang senada juga dilakukan oleh (Maulidar et al., 2019), hasil penelitian tersebut menunjukkan adanya hubungan intensitas bermain Game Online dengan prestasi belajar siswa SD Neger 2 Banda Aceh dengan nilai koefisien $r$ sebesar 0,70 yang berarti memiliki korelasi tinggi. Penelitian yang senada juga dilakukan oleh (Kautsar, 2019) dengan hasil penelitian yaitu terdapat pengaruh Game Online terhadap prestasi akademik di MAN 3 Aceh dapat disimpulkan bahwa tingkat intensitas/kecanduan bermain Game Online pada peserta didik dikatakan tinggi. Penelitian yang senada juga dilakukan oleh (Pangestika, 2017) dengan hasil penelitian menunjukkkan adanya pengaruh antara Game Online dengan prestasi belajar siswa kelas V Sekolah Dasar.

Berdasarkan beberapa penelitian di atas dapat disimpulkan bahwa terdapat korelasi tingkat kecanduan Game Online Mobile Legends dengan prestasi belajar mahasiswa prodi pendidikan matematika Fakultas Tarbiyah dan Keguruan Universitas Islam Negeri Raden Intan Lampung dengan nilai koefisien korelasi sebesar 0,307 masuk ke dalam kategori rendah.

Berdasarkan hasil penelitian yang dilakukan oleh penulisi dan berdasarkan beberapa penelitian terdahulu maka dapat disimpulkan bahwasanya kecanduan game online dapat mempengaruhi prestasi belajar seseorang. Akan tetapi hasil penelitian kali ini yang dilakukan oleh penulis pada mahasiswa prodi pendidikan matematika Fakultas Tarbiyah dan Keguruan Universitas Islam Negeri Raden Intan Lampung menunjukkan bahwa nilai koefisien korelasi rendah yaitu 0,307. Hal 
Jurnal Lebesgue : Jurnal Ilmiah Pendidikan Matematika, Matematika dan Statistika

Diki Irwandi, Ruhban Masykur, Suherman

Volume 2, No. 3, Desember 2021 hal.292-299

DOI Artikel : 10.46306/lb.v2i3.87

ini dikarenakan mahasiswa mampu memanajemen waktu antara bermain Game Online dengan belajar.

\section{KESIMPULAN}

Berdasarkan hasil penelitian yang dilakukan oleh penulis dan berdasarkan beberapa penelitian terdahulu maka dapat disimpulkan bahwasanya kecanduan game online dapat mempengaruhi prestasi belajar seseorang. Akan tetapi hasil penelitian kali ini yang dilakukan oleh peneliti pada mahasiswa pendidikan matematika angkatan 2017 Fakultas Tarbiyah dan Keguruan Universitas Islam Negeri Raden Intan Lampung menunjukkan bahwa nilai koefisien korelasi rendah yaitu 0,307. Hal ini dikarenakan mahasiswa mampu memanajemen waktu antara bermain Game Online dengan belajar. Kekurangan dalam penelitian ini yaitu penulis hanya memfokuskan pada mahasiswa yang bermain Game Online Mobile Legends, padahal terdapat Game Online lainnya.

\section{DAFTAR PUSTAKA}

Alqusyairi, M. S. A., Farida, F., \& Suherman, S. (2021). HUBUNGAN LITERASI LINGKUNGAN DAN LITERASI MATEMATIS TERHADAP KEMAMPUAN COMPUTER SELF EFFICACY. Lebergue: Jurnal Ilmiah Pendidikan Matematika, Matematika, Dan Statistika, 2(2), 153-165.

Astuti, S. P. (2015). Pengaruh kemampuan awal dan minat belajar terhadap prestasi belajar fisika. Formatif: Jurnal Ilmiah Pendidikan MIPA, 5(1).

Chung, L.-Y., \& Chang, R.-C. (2017). The effect of gender on motivation and student achievement in digital game-based learning: A case study of a contented-based classroom. Eurasia Journal of Mathematics, Science and Technology Education, 13(6), 2309-2327. https://doi.org/10.12973/eurasia.2017.01227a

Chusni, M. M., \& Suherman, S. (2021). Developing authentic assessment instrument based on multiple representations to measure students' critical thinking skills. Momentum: Physics Education Journal, 5(23), 194-208. https://doi.org/10.21067/mpej.v5i2.5790

Ehwanudin, M. (2020). Hubungan intensitas bermain game online dengan perilaku keagamaan peserta didik di smp muhammadiyah plus salatiga tahun pelajaran 2019/2020.

Ghullam Hamdu. Lisa Agustina. (2011). Pengaruh Motivasi Belajar Siswa Terhadap Prestasi Belajar IPA di Sekolah Dasar. Penelitian Pendidikan, 12, no. 1, 83.

Hanief, Y. N., \& Himawanto, W. (2018). Statistik Pendidikan (Issue April). https://doi.org/10.31227/osf.io/judwx

Huda, S., Rinaldi, A., Suherman, S., Sugiharta, I., Astuti, D. W., Fatimah, O., \& Prasetiyo, A. E. (2019). Understanding of Mathematical Concepts in the Linear Equation with Two Variables: Impact of E-Learning and Blended Learning Using Google Classroom. AlJabar: Jurnal Pendidikan Matematika, 10(2), 261-270. https://doi.org/10.24042/ajpm.v10i2.5303

Jannah, N., \& Nirwana, H. (2015). Hubungan Kecanduan Game dengan Motivasi Belajar Siswa dan Implikasinya Terhadap Bimbingan dan Konseling. 4(December).

Julia, P. (2018). Hubungan antara Kecanduan Game Online terhadap Prestasi Belajar Siswa SD Negeri 53 Banda Aceh. Jurnal Serambi Akademica, 6(1), 49-57. 
Kautsar, K. (2019). Pengaruh Game Online Terhadap Prestasi Akademik Peserta Didik Di Man 3 Aceh Besar. UNIVERSITAS ISLAM NEGERI AR-RANIRY BANDA ACEH.

Maulidar, Hambali, \& Aklima, F. N. (2019). Hubungan Intensitas Bermain Game Online Dengan Prestasi Belajar Siswa Di Sd Negeri 2 Banda Aceh. 6(2), 302-310.

Pangestika, N. R. (2017). Pengaruh Game Online Terhadap Konsentrasi dan Prestasi Belajar Siswa kelas V Sekolah dasar. Universitas Muhammadiyah Purwokerto.

Putra, F. F., Rozak, A., Perdana, G. V., \& Maesharoh, I. (2019). Dampak Game Online Terhadap Perubahan Perilaku Sosial Mahasiswa Telkom University. Jurnal Politikom Indonesiana, 4(2), 98-103.

Putra, N. K. W. (2017). Pengaruh Game Online Terhadap Motivasi Belajar Siswa Kelas Xi Smk Pgri 4 Kediri Tahun Pelajaran 2016/2017. Artikel Skripsi Universitas Nusantara PGRI Kediri, 01(07), 1.

Putra P, S. A. (2017). Hubungan Kecanduan Bermain Game Online Pada SmartPhone (Mobile Online Games) Terhadap Prestasi Akademik Mahasiswa Angkatan 2013 Fakultas Kedokteran Univesitas Lampung. Universitas Lampung.

Ramadani Febri Iqbal Muhammad. (2018). Penarikan Diri dalam Game Online (Studi Deskripif Kualitatif Withdrawal Gamer Mobile Legends Mahasiswa Ilmu Komunikasi UMS 2014). Universitas Muhammadiyah Surakarta.

Ramadhan, I., Nursuprianah, I., \& Raharjo, H. (2020). Kecanduan Bermain, Game Online , Prestasi Belajar. Al Khawarizmi, 4(2), 153-170.

Sugiyono. (2015). Metode Penelitian Kuantitatif, Kualitatif dan R\&D (ke-22). ALFABETA.

Suherman, Rahmadani, N. A., Vidákovich, T., Mujib, Fitria, N., Sari Putri, N. I., Addarojat, M. R. U., \& Priadi, M. (2021). SQ3R method assisted by ethnomathematics-oriented student worksheet: The impact of mathematical concepts understanding. IOP Conference Series: Earth and Environmental Science, 1796(1). https://doi.org/10.1088/17426596/1796/1/012059

Wibisono, A., \& Naryoso, A. (2019). Hubungan Antara Intensitas Bermain Game Mobile Legend Dan Pengawasan Orang Tua Dengan Perilaku Agresif Verbal Pada. 000, 1-9.

Yunianto, T., Suyadi, S., \& Suherman, S. (2020). Pembelajaran abad 21: Pengaruhnya terhadap pembentukan karakter akhlak melalui pembelajaran STAD dan PBL dalam kurikulum 2013. Premiere Educandum: Jurnal Pendidikan Dasar Dan Pembelajaran, 10(2), 203214. 